\title{
MORTAR DATING METHODOLOGY: ASSESSING RECURRENT ISSUES AND NEEDS FOR FURTHER RESEARCH
}

\author{
Roald Hayen ${ }^{1 *} \cdot$ Mark Van Strydonck $^{1} \cdot$ Laurent Fontaine $^{1} \cdot$ Mathieu Boudin $^{1} \bullet$
} Alf Lindroos ${ }^{2}$ Jan Heinemeier ${ }^{3}$ Åsa Ringbom ${ }^{4} \cdot$ Danuta Michalska $^{5} \cdot$ Irka Hajdas $^{6}$ • Sophie Hueglin ${ }^{7} \cdot$ Fabio Marzaioli $^{8} \cdot$ Filippo Terrasi $^{8} \bullet$ Isabella Passariello $^{8}$ • Manuela Capano $^{8} \cdot$ Francesco Maspero $^{9}$ Laura Panzeri $^{10}$ - Anna Galli ${ }^{10,11} \cdot$ Gilberto Artioli $^{12}$ • Anna Addis ${ }^{12} \cdot$ Michele Secco $^{12} \cdot$ Elisabetta Boaretto $^{13} \cdot$ Christophe Moreau $^{14} \bullet$ Pierre Guibert ${ }^{15} \cdot$ Petra Urbanova $^{15} \cdot$ Justyna Czernik $^{16} \cdot$ Tomasz Goslar $^{16,17} \cdot$ Marta Caroselli $^{18}$

${ }^{1}$ Royal Institute for Cultural Heritage, Jubelpark 1, 1000 Brussels, Belgium.

${ }^{2}$ Dept. of Geology and Mineralogy, Åbo Akademi University, Finland.

${ }^{3}$ Aarhus AMS Centre, Department of Physics and Astronomy, Aarhus University, Denmark.

${ }^{4}$ Department of Art History, Åbo Akademi University, Finland.

${ }^{5}$ Institute of Geology, Adam Mickiewicz University, ul. Bogumiła Krygowskiego 12, 61-680 Poznań, Poland.

${ }^{6}$ Laboratory of Ion Beam Physics, ETHZ, Otto-Stern-Weg 5, 8093 Zurich, Switzerland.

${ }^{7}$ School of History, Classics and Archaeology, Newcastle University, United Kingdom.

${ }^{8}$ CIRCE and Seconda Università degli Studi di Napoli, Dip. di Scienze Ambientali, Italy.

${ }^{9}$ CUDAM, Università di Milano-Bicocca, piazza della Scienza 4, 20126 Milan, Italy, and INFN.

${ }^{10}$ Dipartimento di Scienza dei Materiali, Università di Milano-Bicocca, via R. Cozzi 55, 20125 Milan, Italy, and INFN.

${ }^{11}$ CNR-IFN, Piazza L. Da Vinci 32, 20133 Milan, Italy.

${ }^{12}$ Dipartimento di Geoscienze, Università di Padova, Italy.

${ }^{13}$ Max Planck-Weizmann Center for Integrative Archaeology and Anthropology, D-REAMS Radiocarbon Dating Laboratory, Weizmann Institute, Israel.

${ }^{14}$ LMC14, CEA/Saclay, France.

${ }^{15}$ IRAMAT-CRP2A, UMR5060 CNRS-Université Bordeaux Montaigne, Maison de l'Archéologie, Esplanade des Antilles, 33607 Pessac, France.

${ }^{16}$ Poznań Radiocarbon Laboratory, Poznań Park of Science and Technology, ul. Rubież 46, 61-612 Poznań, Poland.

${ }^{17}$ Faculty of Physics, Adam Mickiewicz University, ul. Umultowska 85, 61-614 Poznań, Poland.

${ }^{18}$ Univ. of Applied Sciences of Southern Switzerland, Switzerland.

\begin{abstract}
Absolute dating of mortars is crucial when trying to pin down construction phases of archaeological sites and historic stone buildings to a certain point in time or to confirm, but possibly also challenge, existing chronologies. To evaluate various sample preparation methods for radiocarbon $\left({ }^{14} \mathrm{C}\right)$ dating of mortars as well as to compare different dating methods, i.e. ${ }^{14} \mathrm{C}$ and optically stimulated luminescence (OSL), a mortar dating intercomparison study (MODIS) was set up, exploring existing limits and needs for further research. Four mortar samples were selected and distributed among the participating laboratories: one of which was expected not to present any problem related to the sample preparation methodologies for anthropogenic lime extraction, whereas all others addressed specific known sample preparation issues. Data obtained from the various mortar dating approaches are evaluated relative to the historical framework of the mortar samples and any deviation observed is contextualized to the composition and specific mineralogy of the sampled material.
\end{abstract}

KEYWORDS: lime, mortar dating, OSL, radiocarbon AMS dating.

\section{INTRODUCTION}

The possibility to use radiocarbon $\left({ }^{14} \mathrm{C}\right)$ dating as a tool for mortar dating was introduced as early as the 1960s (Labeyrie and Delibrias 1964; Baxter and Walton 1970). ${ }^{14} \mathrm{C}$ dating of mortars relies on the anthropogenic lime carbonates that form during the hardening of the lime mortar; this process is called carbonation (Boynton 1980). Hardening through carbonation is obvious in the case of practically pure putty lime binders, which are almost entirely composed of calcium hydrate. However, also in the case of hydraulic binders, carbonation plays a role in the hardening process because the hydraulic binder may already contain calcium hydrate or calcium hydrate is formed as a reaction product of the hydration of the hydraulic phases, the

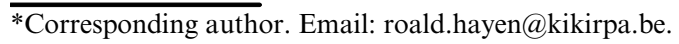


so-called secondary formation of calcium hydrate. As the complete hydration of a hydraulic binder is generally a question of months, the secondary formation of calcium hydrate has no significant influence on the dating process itself.

For a successful mortar dating it is crucial to separate the anthropogenic lime carbonate from possibly intervening carbon dioxide sources, such as firstly limestone fragments found in insufficiently burnt residues of the limestone originally used for the binder production, secondly limestone fragments or micro-fossils of geogenic origin present within calcareous or siliceous aggregates, and thirdly (re)crystallized secondary deposits and products of delayed hardening away from the exterior surface (Sonninen et al. 1984). As fossil carbonates are much older than the anthropogenic carbonate, they will artificially increase the age of the mortar sample by decreasing its ${ }^{14} \mathrm{C} /{ }^{12} \mathrm{C}$ abundance ratio. Secondary carbonation deposits, on the contrary, will have the opposite effect as they are formed after the initial hardening of the mortar. These are formed when free lime hydrate, which is easily dissolved in the pore water and, hence, can migrate through the mortar, is deposited in fine capillary pores and/or cracks near to the surface where it reacts with atmospheric $\mathrm{CO}_{2}$. Secondary carbonation deposit formation depends on the availability of free lime hydrate and regular moisture migration through the mortar. Hence, it is most often only observed under very humid conditions typical for subterranean structures (foundations, cellars, etc.) and bridges.

Another approach to mortar dating is to study the dosimetric properties of the quartz and feldspar minerals, which are determined by the time elapsed since the sand grains within the aggregate were last exposed to sunlight (Urbanova et al. 2015; Urbanova and Guibert 2017). In theory, the sequence of events leading to the preparation of a mortar, from the extraction of the sand in a quarry, its transport to a building yard to the mixing with a lime binder, should allow for the bleaching and resetting of the ionizing radiation of these minerals. Therefore, the measurement of the optically stimulated luminescence (OSL), or the amount of energy accumulated since this last exposure of the sand components in the mixture to light, is another way to date historic mortars.

\section{METHODOLOGY}

A crucial process to achieve correct results in mortar dating is the adequate pretreatment of the sample in order to separate the anthropogenic lime carbonate from other carbon dioxide sources. Separation of the anthropogenic from other lime carbonates is usually realized by means of stepwise acid hydrolysis (Folk and Valastro 1976; Folk and Valastro 1979; Van Strydonck et al. 1986; Heinemeier et al. 1997), as it has long since been assumed that the softer anthropogenic carbonate will react first while the harder rock carbonates will resist longer to the acid attack (Folk and Valastro 1979; Sonninen and Jungner 2001; Lindroos et al. 2010; Nawrocka et al. 2009). As the reaction proceeds, the relative amount of fossil carbonates dissolved increases, generally revealing steadily older ${ }^{14} \mathrm{C}$-ages. Different stepwise acid hydrolysis approaches exist, varying in type of the acid (hydrochloric acid, phosphoric acid) and reaction conditions (immediate complete immersion versus phased addition, acid concentration). The other pretreatment procedure, the cryobreaking method (Nawrocka et al. 2005; Marzaioli et al. 2013), relies on (gently) grinding, thermally breaking and sieving of the mortar samples prior to a one-step acid hydrolysis of a selected fraction. All above described methods can be used either on bulk mortar or on individual lime lumps of suitable size.

For OSL-measurement, the pretreatment of bulk mortar samples requires the material to be crushed and sieved followed by acid hydrolysis with hydrochloric and hydrofluoric acids. The preparation is realized under a dim red light to prevent bleaching of the minerals. Important here is to avoid light contamination during the sampling procedure itself. 
Table 1 Overview of the laboratories involved in MODIS with the abbreviation codes and the methods applied $\left(\mathrm{ACH}=\right.$ acid hydrolysis in combination with ${ }^{14} \mathrm{C}$-dating, $\mathrm{CRY}=$ cryobreaking in combination with ${ }^{14} \mathrm{C}$-dating, OSL $=$ OSL-dating on the minerals, and $\mathrm{MID}=$ mortar composition analysis).

\begin{tabular}{lll}
\hline Laboratory & Code & Methods \\
\hline Aarhus University (Denmark)/Åbo Akademi University (Finland) & ABO & ACH \& MID \\
$\begin{array}{l}\text { Institute of Geology and Faculty of Physics Adam Mickiewicz } \\
\text { University (Poland) and Poznań Radiocarbon Laboratory }\end{array}$ & POZN & MID, ACH \& \\
CIRCE \& Seconda Università degli Studi di Napoli (Italy) & CRY \\
CNRS/Université Bordeaux Montaigne (France) & IRA CRY \\
ETH Zürich (Switzerland) & ETHZ ACH \\
LMC14/CEA (France) & LMC ACH \\
Royal Institute of Cultural Heritage, Brussels (Belgium) & RICH ACH \& MID \\
Università degli Studi Milano-Bicocca, CNR-IFN \& INFN (Italy) & MIL & ACH \& OSL \\
Università di Padova (Italy) & CIRCe CRY \\
Weizmann Institute (Israel) & WEIZ & MID \\
\hline
\end{tabular}

A comprehensive and detailed overview of the various methods is presented in these proceedings (Hajdas et al. 2017; Michalska et al. 2017). See Table 1 for an overview of the involved laboratories and the abbreviations used.

\section{MATERIALS}

Four mortar samples were selected and distributed among the participating laboratories. The samples are a lime conglomerate from a burial site at Cova S'Estora (Son Pellisser) on the island of Mallorca (Spain), a bedding mortar/infill from the lower part of a Roman wall excavated in the city of Tongeren (Belgium), the remains of a Medieval mortar mixer from Basel Cathedral Hill (Switzerland) and a wall's bedding mortar from the church of Nagu in the Åboland archipelago (Finland).

The lime conglomerate from the burial site of Cova S'Estora is not a mortar in the strict sense. Lime burials are an enigmatic practice in Balearic Protohistory. They are the result of a special cremation rite. Before being incinerated on a pyre, the bodies must have been covered - in a yet unidentified manner-with very fine crushed limestone. The heat of the pyre then would decompose the limestone $\left(\mathrm{CaCO}_{3}\right)$, much like when producing lime for mortar. However, unlike the firing of traditional lime kilns, the cremation pyre was less controlled. The incomplete outgassing of the limestone during cremation occurred regularly, increasing the risk of introducing remnants of the fossil rock carbonate in the lime burial.

The second mortar sample is a so-called cocciopesto, a mortar that additionally contains crushed fragments of earthenware or bricks. It was obtained from a recently excavated part of the 4th century city wall of the Roman civitas Aduatuca Tungrorum, today Tongeren in Belgium. The sample was taken a few centimeters from below the surface of wall remains that originally came from the rising part of the structure. Actually, the wall was being destroyed to build an underground parking lot. The external façade of the Roman wall had very wide mortar joints so that the bedding mortar would continue through to the mortar used for the central infill of the wall. The mortar was selected and included in the study, as earlier attempts to date cocciopesto type mortars so far have failed (Ringbom et al. 2011, 2014; Michalska and Czernik 2015). 
The Swiss mortar sample comes from a mechanical mortar mixer, excavated in 2004 on the northern part of Cathedral Hill in Basel (Hueglin 2011, 2017). Charcoal fragments from the well-preserved remains were ${ }^{14} \mathrm{C}$-dated to the 10 th or early 11 th century AD. The sample was taken from the mortar remnants found at the bottom of the mixer.

The mortar of the Nagu church was taken in the nave's attic from the arcade walls above the vaults. Based on ${ }^{14} \mathrm{C}$-dating of preserved wooden roof trusses and scaffolding, the nave is believed to have been constructed in the first half of the 15th century (Lindroos et al. 2007; Sjöberg et al. 2011). Upon sampling, the mortar was described as soft, finely grained, and containing at first sight not much of a filler. However, a lot of white lumps smaller than $10 \mathrm{~mm}$ were present, of which some had already been dated earlier by $\mathrm{ABO}$. Acid hydrolysis with $3 \% \mathrm{HCl}$ yielded a ${ }^{14} \mathrm{C}$-age of $584 \pm 36 \mathrm{BP}$, whereas a test with $5 \% \mathrm{H}_{3} \mathrm{PO}_{4}$ resulted in a ${ }^{14} \mathrm{C}$-age of $445 \pm 51 \mathrm{BP}$.

A detailed description of the composition of the four mortar samples can be found in Hayen et al. (2016).

\section{OVERVIEW AND EVALUATION OF RESULTS}

\section{Lime Conglomerate from Cova S'Estora (Mallorca, Spain)}

The lime burial layers of Cova S'Estora are thought to date from the Iron Age. Situated chronologically within the so-called Hallstatt plateau, a flat section of the calibration curve between ca. 800 and $400 \mathrm{BC}$, a precise ${ }^{14} \mathrm{C}$-dating was not to be expected. Stratigraphic analysis of the lime conglomerate combined with ${ }^{14} \mathrm{C}$-dates obtained from charcoal remains and a bone fragment situate the lime burial of Cova S'Estora somewhere between 751 and 407 BC. The charcoal was obtained from a layer underneath the lime burial, predating the tradition of adding finely crushed limestone to the pyre, whereas the bone fragment was found within the lime burial itself (Table 2 and Figure 1). In addition, the petrographic analysis of the lime conglomerate revealed a loosely coherent and heavily fractured binder mass containing various large lime lumps, wherein unburnt

Table 2 Overview of the results obtained for the lime conglomerate from Cova S'Estora (Mallorca, Spain). The ${ }^{14} \mathrm{C}$-ages are listed with the according $2 \sigma$ standard deviation as well as the calibrated calendar dates with $95.4 \%$ certainty according to the IntCal13 atmospheric curve. Reference dates are marked in bold.

\begin{tabular}{|c|c|c|c|}
\hline Laboratory & Sample, method description & ${ }^{14} \mathrm{C}$ age $(2 \sigma)$ & Calibrated date \\
\hline $\mathrm{ABO}$ & $\begin{array}{l}\text { Bulk powder, fraction } 46-75 \mu \mathrm{m}, 0-8 s \text { of } \\
\text { reaction }\end{array}$ & $2378(25)$ & $522 \mathrm{BC}-396 \mathrm{BC}$ \\
\hline \multirow[t]{2}{*}{ CIRCE } & Bulk mortar, suspension & $3258(23)$ & $1613 \mathrm{BC}-1460 \mathrm{BC}$ \\
\hline & powder, suspension & $3052(23)$ & $1401 \mathrm{BC}-1231 \mathrm{BC}$ \\
\hline CIRCe & & $3157(44)$ & $1517 \mathrm{BC}-1300 \mathrm{BC}$ \\
\hline ETHZ & $\begin{array}{l}\text { Fraction } 45-63 \mu \mathrm{m} \text {, average of } 0-3 s \& 4-6 \\
s \text { of reaction }\end{array}$ & $2352(69)$ & $756 \mathrm{BC}-369 \mathrm{BC}$ \\
\hline \multirow[t]{2}{*}{ MIL } & Lime lump & $2749(39)$ & $993 \mathrm{BC}-816 \mathrm{BC}$ \\
\hline & Bulk mortar & $3136(30)$ & $1496 \mathrm{BC}-1303 \mathrm{BC}$ \\
\hline POZN & Fraction $80-100 \mu \mathrm{m}, 0-2$ s of reaction & $2381(60)$ & $756 \mathrm{BC}-369 \mathrm{BC}$ \\
\hline \multirow[t]{4}{*}{$\mathrm{RICH}$} & Top of lime burial layer & $2451(31)$ & $755 \mathrm{BC}-411 \mathrm{BC}$ \\
\hline & Base of lime burial layer & $2554(30)$ & $804 \mathrm{BC}-551 \mathrm{BC}$ \\
\hline & Charcoal found at bottom of layer & $2436(30)$ & $751 \mathrm{BC}-407 \mathrm{BC}$ \\
\hline & Bone fragment from lime burial layer & $2442(30)$ & $752 \mathrm{BC}-409 \mathrm{BC}$ \\
\hline
\end{tabular}




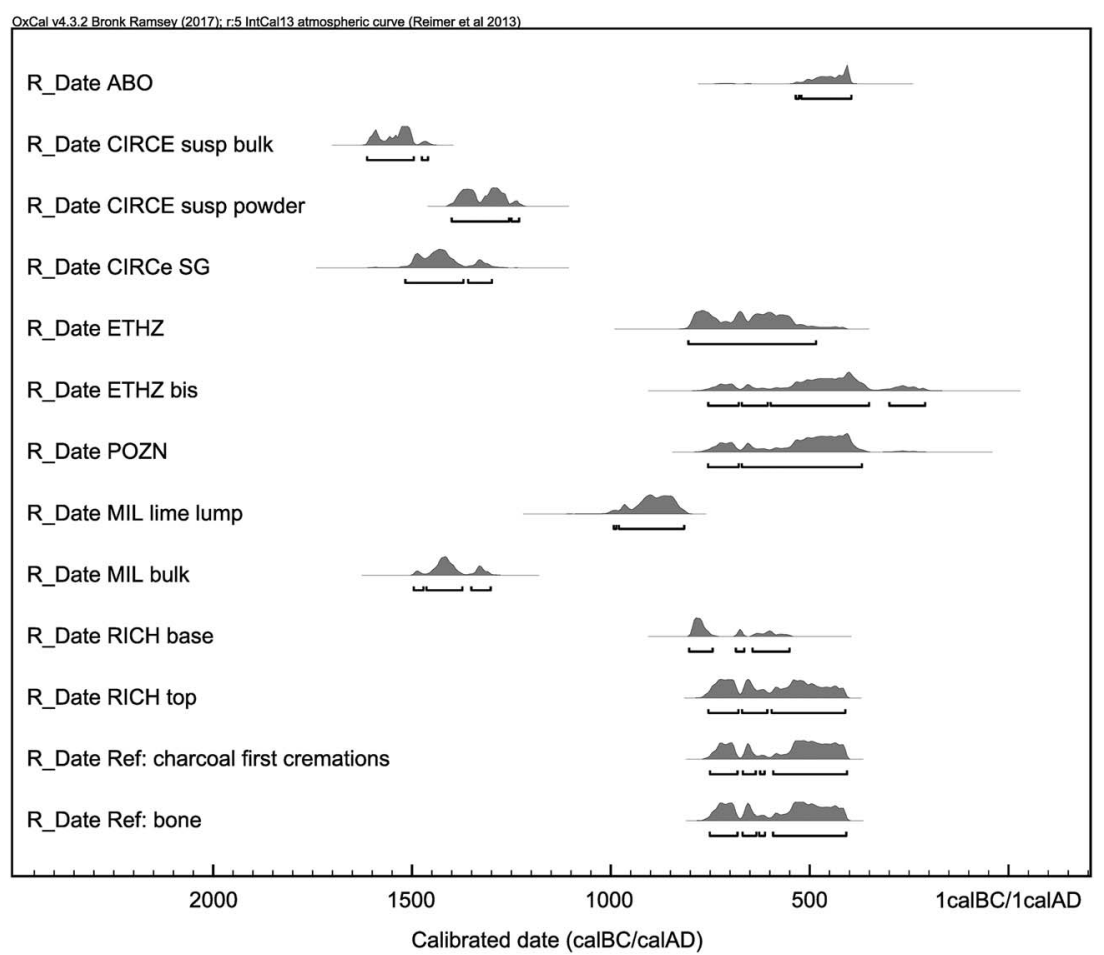

Figure 1 Overview of the results obtained for the lime conglomerate from Cova S'Estora (Mallorca, Spain).

fragments of a dolomitic limestone could be recognized. With both hydromagnesite and dolomite present, this could be considered a potential risk for the dating process.

Data obtained by ABO, ETHZ, and POZN do confirm earlier results on the lime conglomerate as obtained by RICH and in agreement with the expected chronology. However, all of the other results reveal ages older than the established chronology of the lime burial rite on the Balearic Islands. Although comparable approaches based on the stepwise acid hydrolysis were applied by MIL with material selected from lime lumps, the preparation of the samples clearly did not succeed in sufficiently separating the anthropogenic lime carbonates from the fossil limestone. On the other hand, the very nature of the loosely coherent and heavily fractured binder mass probably impeded a successful separation of the anthropogenic lime carbonates following the cryosonic method (CIRCe) in this particular case. Both CIRCe and MIL data for the bulk samples, which may - if present - contain higher amounts of geogenic contaminants, evidence the strong contamination of the lime conglomerate with geogenic material as determined from petrographic analysis.

As the lime conglomerate did not contain any mineral aggregates, OSL could not be performed on the sample.

\section{Roman Cocciopesto Mortar from Tongeren (Belgium)}

The expected date for the cocciopesto mortar from the Roman city wall was the 4th century $\mathrm{AD}$; this is based on the occupation history of the site and archaeological findings in the immediate surroundings. The chronology was confirmed by the ${ }^{14} \mathrm{C}$-dating of a charcoal 
fragment found within the cocciopesto mortar (Table 3 and Figure 2). Although the results from various laboratories more or less agree, the data obtained from the mortar place the hardening process somewhere between the end of the 9th and the 14th centuries AD, which clearly does not agree with the expected age. Only the analysis by POZN of the $80-100 \mu \mathrm{m}$ fraction reveals a somewhat earlier period (5th to 9th century AD), which is still far too young.

Petrographic analysis of the mortar reveals a composition of dolomitic lime and roughly crushed terracotta with fragments as large as several centimeters in size. Moreover, there were indications that the mortar had gone through a series of dissolution and precipitation cycles. Based on the material characterization, the presence of limestone fragments, its pozzolanic nature, and the assumption of weathering, there was a high probability that it would not be possible to date the erection of the wall. It was very likely that there would be interferences with geogenic carbonates as well as with phenomena like (partial) recrystallization or late hardening of the binder matrix. The data obtained by ${ }^{14} \mathrm{C}$ dating reveal that fossil carbonates most likely did not interfere and hence had been effectively eliminated. However, leaching of the portlandite in combination with secondary deposits (delayed hardening) and possible recrystallization of the dissolved lime binder, led to a younger age of the mortar sample and most probably is the reason for the obtained results.

Another issue that has to be mentioned here is the eminent pozzolanicity of the cocciopesto mortar, i.e., the chemical interaction of the crushed tiles with the portlandite leading to the formation of calcium-silicate-hydrates, which have the property to react with water (hydraulic reaction). In the past, dating of constructions built with pozzolanic mortars has proven to be difficult. The problematic nature of this binder and its carbonate crystallization history was the reason why the sample was included in MODIS. Delayed hardening is a phenomenon well known to occur in hydraulic pozzolana, but with cocciopesto mortars the pozzolanic reaction, provoked by the interaction of the lime hydrate with the crushed ceramics or bricks

Table 3 Overview of the results obtained for the Roman cocciopesto type mortar from Tongeren (Belgium). The ${ }^{14} \mathrm{C}$-ages are listed with the according $2 \sigma$ standard deviation as well as the calibrated calendar dates with $95.4 \%$ certainty according to the IntCal13 atmospheric curve. Reference dates are marked in bold.

\begin{tabular}{llrl}
\hline Laboratory & Sample, method description & ${ }^{14}$ C age $(2 \sigma)$ & Calibrated date \\
\hline ABO & Crushed lime lump & $712(25)$ & 1260 AD-1381 AD \\
CIRCE & Suspension & $979(23)$ & 1014 AD-1153 AD \\
CIRCe & SG1 & $1063(24)$ & 900 AD-1021 AD \\
& SG1b & $1070(22)$ & 899 AD-1019 AD \\
& SG2 & $1056(24)$ & 901 AD-1024 AD \\
& Lime lump & $972(24)$ & 1016 AD-1155 AD \\
ETHZ & Fraction 32-63 $\mu \mathrm{m}$, mean value 1-3 \& 4-6 s of & $862(34)$ & 1046 AD-1258 AD \\
& reaction & $903(32)$ & 1037 AD-1208 AD \\
MIL & & $930(40)$ & 1022 AD-1189 AD \\
POZN & Fraction 40-63 $\mu \mathrm{m}, 0-2$ s of reaction & $1110(30)$ & 879 AD-1013 AD \\
& Fraction 80-100 $\mu \mathrm{m}$ from suspension & $1380(80)$ & 433 AD-865 AD \\
& Fraction 80-100 $\mu \mathrm{m}, 1$ s of reaction & $972(35)$ & 999 AD-1157 AD \\
RICH & Acid hydrolysis with HCl in 7 fractions & $1029(30)$ & 901 AD-1117 AD \\
& Acid hydrolysis with HCl in 200 fractions & $\mathbf{1 7 3 9 ( 3 2 )}$ & 234 AD-389 AD \\
\hline
\end{tabular}




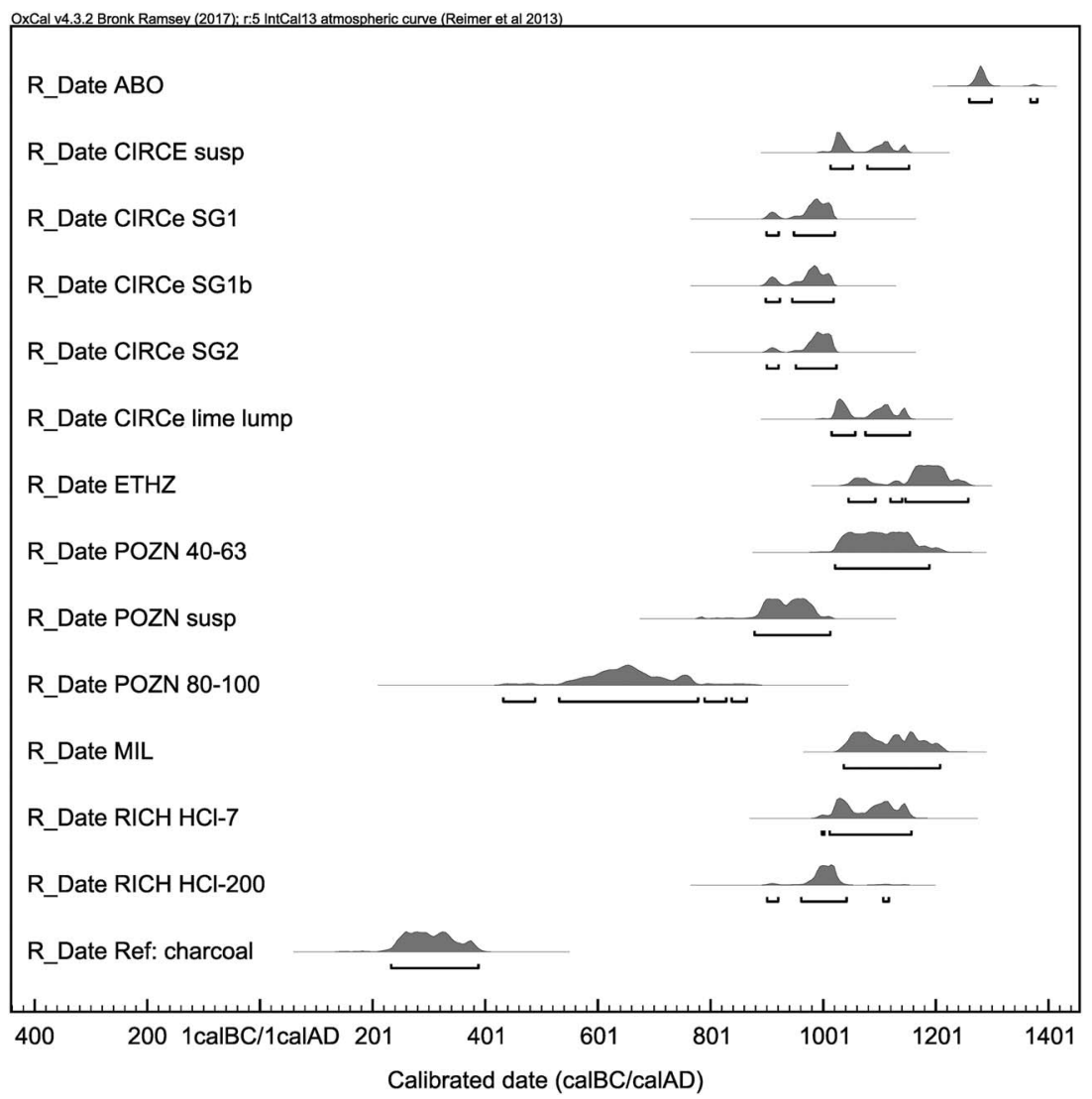

Figure 2 Overview of the results obtained for the Roman cocciopesto type mortar from Tongeren (Belgium).

(Binda 1988), is even more extreme (Blake 1959; Lancaster 2005). Furthermore, the effect of delayed hardening is strongly influenced here by the impermeability of the cocciopesto mortar to water, which influences the water uptake and hence the hydraulic pozzolanic reaction and the carbon dioxide migration as both processes are influenced by the moisture present. In addition, the effect of pozzolanicity also interferes with the leaching and recrystallization of the lime binder. Also, it must not be forgotten here, that the mortar sample was taken at a considerable depth. Therefore, based on this mortar sample alone, it will not be possible to assess whether it will be possible to date the initial hardening of pozzolanic mortars. Further research is certainly needed to establish whether the problem is related to the pozzolanic reaction (alone) or not.

The discrepancy between the expected age and the data obtained does not necessarily mean that here mortar dating has failed. The consistent result may indicate that there was an actual moment when the processes of delayed hardening and recrystallization of the lime binder came to an end and was correctly identified. This would of course not reveal the expected erection date of the construction. In this case, the date obtained could rather have to do with the moment the wall finally fell into disuse and was destructed, which could have led to exposure of the inner parts of the wall to water and carbon dioxide and would have led to the final hardening of the cocciopesto mortar. So, with hydraulic and pozzolanic mortars radiocarbon dating might offer a possibility to determine the destruction of a monument, by taking samples from the core of thick walls. 


\section{Medieval Mortar Mixer from Basel Cathedral Hill (Switzerland)}

The Basel mortar sample was expected to produce dates from the Medieval period. The initial date for the sample was derived from its stratigraphic position as well as from a number of charcoal fragments from the mortar itself. Earlier measurements (identified as $\mathrm{Rc} 7$ and $\mathrm{Rc} 8$ ) revealed ${ }^{14} \mathrm{C}$ ages of $1055 \pm 45 \mathrm{BP}$ and $1105 \pm 40 \mathrm{BP}$ (Table 4), respectively, corresponding with a calibrated calendar date between 894 and 1017 AD (initial estimate, 95\% interval; Figure 3). However, in addition to the charcoal, a bone fragment (Rc9) from the late Roman period was found in the mortar, hinting to the presence of older archaeological material in the mortar. ETZH found within the context of MODIS an additional charcoal fragment (identified as MODIS) within the mortar sample, which, according to its ${ }^{14} \mathrm{C}$-dating, predates the initially established chronology by about 200 years. As the mortar mixer had been built by cutting a pit into older "dark earth" strata which contained a lot of Roman material, it was not surprising to find fragments of older organic material also in the mortar. This demonstrates the well-known "old-wood effect," but does not undermine the initially established date of the mortar mixer, as these devices could only be used for one building campaign.

As for the petrographic analysis, the Basel mortar sample can be identified as a very heterogeneous material, containing a poorly sorted quartz sand as an aggregate and numerous, partly burnt, limestone and charred wood particles. The presence of a significant amount of (partially burnt) limestone fragments was expected to possibly interfere with the ${ }^{14} \mathrm{C}$-dating process.

Table 4 Overview of the results obtained for the Medieval mortar mixer from Basel Cathedral Hill (Switzerland). The ${ }^{14} \mathrm{C}$-ages are listed with the according $2 \sigma$ standard deviation as well as the calibrated calendar dates with $95.4 \%$ certainty according to the IntCal13 atmospheric curve. Calendar dates obtained by OSL are presented with the $1 \sigma$ standard deviation in between brackets. Reference dates are marked in bold.

\begin{tabular}{llll}
\hline Laboratory & Sample, method description & ${ }^{14}$ C age $(2 \sigma)$ & Calibrated date \\
\hline ABO & Crushed lime lump & $1820(25)$ & 127 AD-311 AD \\
CIRCE & Susp & $2682(22)$ & 895 BC-803 BC \\
CIRCe & SG1 & $2107(24)$ & 195 BC-54 BC \\
& SG1b & $2084(24)$ & 174 BC-44 BC \\
& SG2 & $2179(49)$ & 379 BC-101 BC \\
& Lime lump & $1648(24)$ & 337 AD-528 AD \\
IRAM & & & 218 AD (179) \\
ETHZ & Mean value of fractions < 40 $\mu$ m \& & $1756(36)$ & 144 AD-387 AD \\
& 40-63 $\mu m, 0-1$ s of reaction & & \\
& Charcoal fragment (Rc7) & $\mathbf{1 0 5 5}(\mathbf{4 5})$ & $\mathbf{8 8 4}$ AD-1118 AD \\
& Charcoal fragment (Rc8) & $\mathbf{1 1 0 5}(\mathbf{4 0})$ & $\mathbf{7 7 8}$ AD-1020 AD \\
& Bbone fragment (Rc9) & $\mathbf{1 6 2 5}(\mathbf{5 5})$ & $\mathbf{2 6 0}$ AD-561 AD \\
& Charcoal fragment (MODIS) & $\mathbf{1 3 1 3}(\mathbf{2 2})$ & $\mathbf{6 5 8}$ AD-767 AD \\
MIL & Lime lump & $3266(44)$ & 1636 BC-1441 BC \\
& Bulk mortar & $3014(30)$ & 1387 BC-1130 BC \\
& OSL & & 130 AD (200) \\
POZN & Grain fraction 80-100 $\mu$, 0-2 s of reaction & $1491(50)$ & 428 AD-650 AD \\
RICH & & $1816(35)$ & 89 AD-325 AD \\
\hline
\end{tabular}




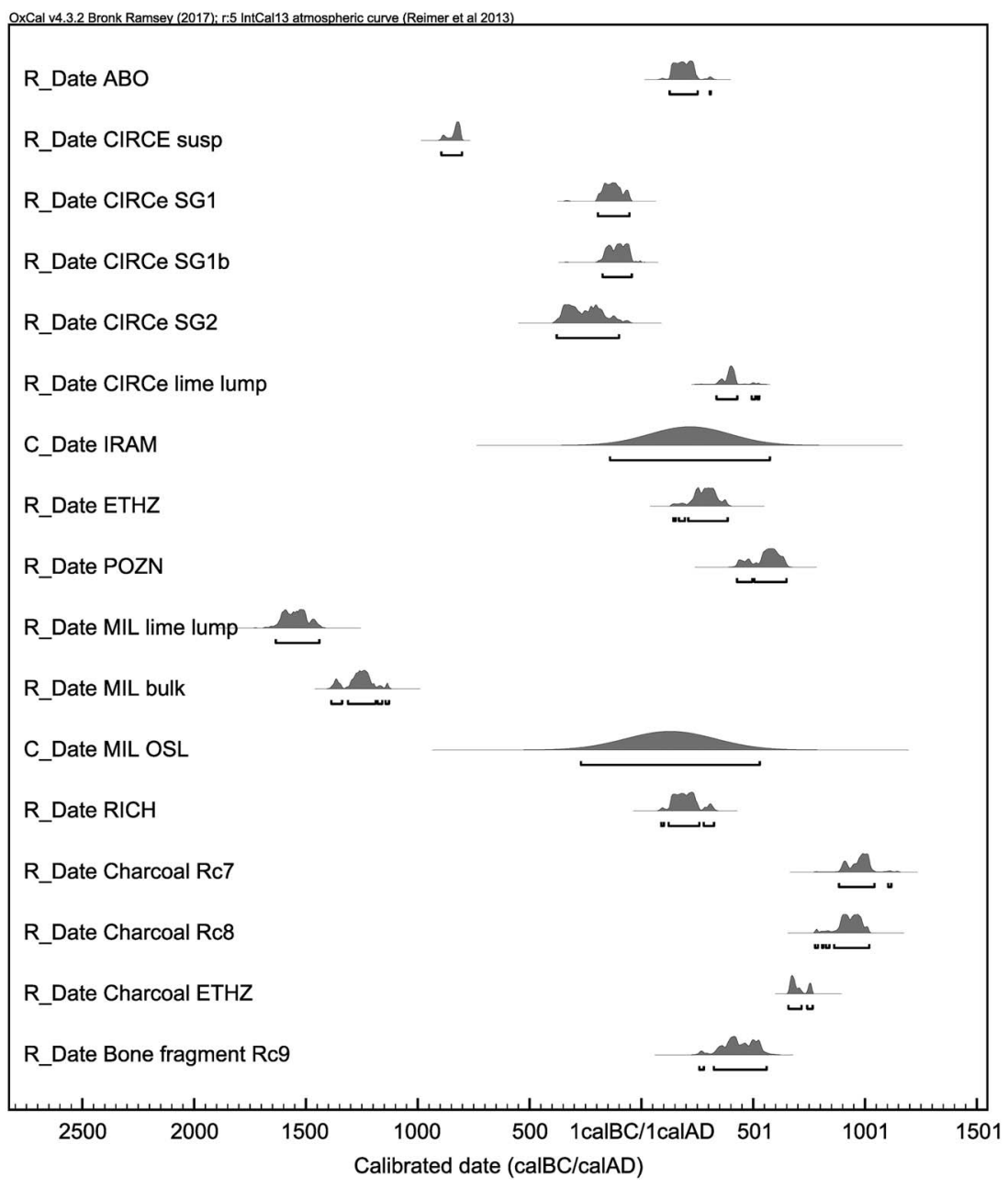

Figure 3 Overview of the results obtained for the Medieval mortar mixer from Basel Cathedral Hill (Switzerland).

The results from ABO, ETHZ, POZN, and RICH as well as the evaluation of the selected lime lumps by CIRCe tend to situate the mortar towards the late Roman or even early Frankish (POZN) period. At first, the evaluation of these data seems to demonstrate the difficulty to separate here the anthropogenic from the geogenic carbonates. The results show a large gap between the initial charcoal dates, that confirm the production of mortar in the Medieval period, and the dates for the formation of lime carbonate and last light exposure of quartz grains (OSL) within the mortar, which point both rather towards a Roman context about 700 years earlier. However, it is difficult to explain the rather consistent early dates solely as the result of geogenic contamination, rather in this case the explanation could lie for example in the lavish reuse of ground Roman mortar as sand component in the Medieval mortar production. To prove this recycling hypothesis, it will need further investigation into the Roman mortars on site.

\section{Wall Bedding Mortar from the Church of Nagu (Finland)}

The wall bedding mortar from the church of Nagu was expected to date to the first half of the 15 th century, as the dates derived from the preserved contemporary wooden roof trusses and 
Table 5 Overview of the results obtained for the wall bedding mortar from the church of Nagu (Finland). The ${ }^{14} \mathrm{C}$-ages are listed with the according $2 \sigma$ standard deviation as well as the calibrated calendar dates with $95.4 \%$ certainty according to the IntCal13 atmospheric curve. Calendar dates obtained by OSL are presented with the $1 \sigma$ standard deviation in between brackets. Reference dates are marked in bold.

\begin{tabular}{|c|c|c|c|}
\hline Laboratory & Sample, method description & ${ }^{14} \mathrm{C}$ age $(2 \sigma)$ & Calibrated date \\
\hline \multirow[t]{2}{*}{$\overline{\mathrm{ABO}}$} & fraction $46-75$ & 463 & 1415 AD-1455 AD \\
\hline & 10 wood fragments, combined calibration & $515(9)$ & 1410 AD-1432 AD \\
\hline CIRCE & Suspension & $628(29)$ & 1288 AD-1399 AD \\
\hline ETHZ & $\begin{array}{l}\text { Fraction } 46-75 \mu \mathrm{m} \text {, mean value } 1-3 \& 4-6 s \\
\text { of reaction }\end{array}$ & $445(35)$ & 1411 AD-1615 AD \\
\hline MIL & $O S L$ & $159(75)$ & $\begin{array}{l}\text { Later than } 1637 \mathrm{AD} \\
990 \mathrm{AD}(70)\end{array}$ \\
\hline POZN & Fraction $80-100 \mu \mathrm{m}, 0-2$ s of reaction & 610( & 1294 AD-1406 AD \\
\hline $\mathrm{RICH}$ & & $493(34)$ & 1330 AD-1454 AD \\
\hline
\end{tabular}

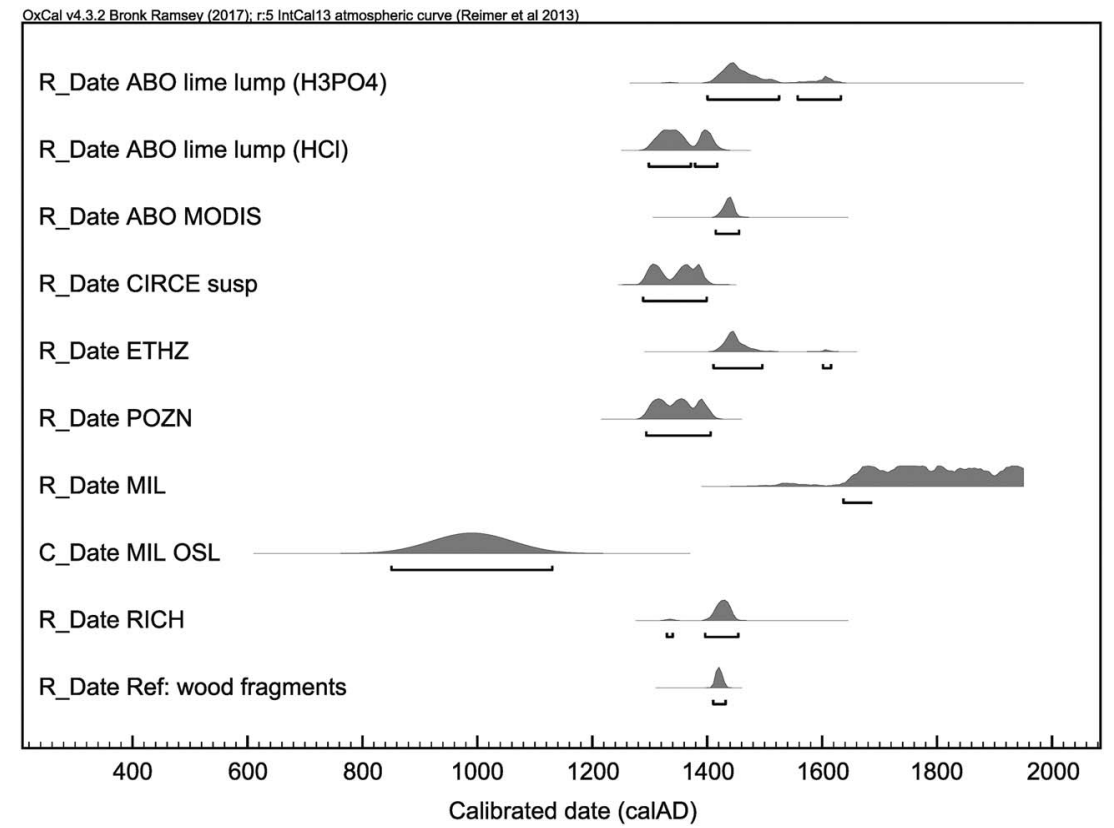

Figure 4 Overview of the results obtained for the wall's bedding mortar from the church of Nagu (Finland).

scaffolding indicate (Table 5 and Figure 4). Petrographic analysis identifies the mortar as a probably slightly hydraulic lime with a granitic sand as aggregate. Within some of the lime lumps remnants of a limestone containing fine quartz grains can be recognized. However, the number of such limestone remnants is small and the inherent risk for interfering with the ${ }^{14} \mathrm{C}$-dating seemed limited. Nevertheless, a careful consideration of the mortar preparation and data interpretation remains necessary, especially whenever a single lime lump would be selected for ${ }^{14} \mathrm{C}$ dating. 
Some of the ${ }^{14} \mathrm{C}$-dating results are in agreement with the expected chronology, especially the ${ }^{14} \mathrm{C}$ data obtained by ABO (MODIS sample), ETHZ and $\mathrm{RICH}$, although various procedures for stepwise acid hydrolysis were applied. The data obtained by ABO (lime lump), CIRCe and POZN, however, are most likely slightly contaminated by geogenic carbonates, based on the clear distinction in ${ }^{14} \mathrm{C}$ age as compared to the earlier mentioned results and the reference ${ }^{14} \mathrm{C}$ age of the wood fragment. Although the mortar sample did not contain particular amounts of geogenic material, individual analyses still seem to have been influenced by its presence. This can be observed especially in the case of the lime lump selected by ABO. The petrographic analysis showed that geogenic lime carbonates seemed to be present especially within the lime lumps of this mortar sample. The data prove the ability of the various methods to date an appropriate mortar sample, but they also show that even if no geogenic material seems to be present, a single measurement is not sufficient to establish a reliable date. Both the ${ }^{14} \mathrm{C}$ age and OSL measurements from MIL fell outside of the possible range of dates.

\section{CONCLUSION}

The combination of mortar analysis and dating methods on four specifically selected mortar samples within this intercomparison project shows the potential as well as the difficulties encountered when trying to understand the hardening process of mortars and through this to date archaeological features and standing buildings. Potentially present limestone and secondary or recrystallization binder deposits are potential sources of error to date the erection of a building, however they tell about mortar production processes and building history. In certain cases, the results might even point to the destruction of a monument.

The evaluation of the MODIS results shows that all the various methods applied for pretreating the mortar samples for ${ }^{14} \mathrm{C}$-dating can - in certain cases - reveal a valuable construction date, but that a concise and independently reliable method cannot yet be described. Stepwise acid hydrolysis revealed both positive and negative results on the same sample containing only small amounts of limestone (Nagu's bedding mortar). Therefore, it still remains difficult to rely upon a single measurement irrespective if a bulk sample or (single or multiple) lime lumps were selected for analysis. The results prove, nevertheless, that the different reaction conditions (type of acid, acid concentration, immediate complete immersion versus phased addition) can reveal identical ${ }^{14} \mathrm{C}$ ages on complex mortar samples such as the poorly burnt lime burial conglomerate or the pozzolanic cocciopesto mortar. Analogous results often were obtained by the cryobreaking and one step acid hydrolysis pretreatment method. An exception here was the loosely coherent and heavily fractured lime conglomerate from the lime burial at Cova S'Estora. Here, the method seems to have difficulty separating the omnipresent geogenic lime carbonates from the anthropogenic material due to the physico-mechanical characteristics of the sample.

On the other hand, the example of the Roman cocciopesto mortar shows that it might never be possible to date the erection of buildings from such mortars due to the very nature and/or formation history of these mortars. As there is a complex interaction between delayed hardening (pozzolanicity) and recrystallization of the dissolved binder due to weathering, the actual contribution of the pozzolanic properties of the mortar could not be established. Further research is also required here to understand whether the obtained date could have to do with the destruction of the Roman city wall and therefore would hint to its end rather than to its beginning.

With the Basel mortar sample, some of the organic reference material demonstrated the old wood-effect, thus demonstrating the difficulty of relying on organic remains when dating mortar. More importantly, there were indications that centuries after, mortar from Roman 
buildings had been reused as ingredient in the Medieval mixing device. Mortar dating therefore might be able to demonstrate reuse and origin of building material on a microscopic level. This would add an important possibility to observe recycling of building materials in the past beyond the macroscopic level.

As for the OSL measurements, only data from the Basel and Nagu church samples could be obtained. Both other samples did not contain a quartz fraction required for OSL dating. In the case of the Nagu mortar the results differ considerably from the ${ }^{14} \mathrm{C}$-data and the established chronology. However, in the case of the Basel mortar sample, the results correlate with most of the calibrated ages based on the ${ }^{14} \mathrm{C}$ dates. The uncertainty of the estimated age, however, remains large. Two approximations could have improved the outcome but could not be performed in this particular case: firstly, environmental measurements of radioactivity on-site would have been required for a precise determination of the annual dose rate, but these could not be taken as the samples analyzed were already removed from their original context. Secondly, the low sensibility of the quartz grains prevented the use of single grain OSL dating method (SG-OSL), which would have been a more accurate dating technique (Urbanova and Guibert, 2017). Instead, the OSL measurements were realized by standard multigrain OSL technique, which may have caused some discrepancies in the determination of the archaeological dose. Research concerning the link between the provenance and the luminescence properties of quartz is currently running in order to explain the low sensibility of the Basel mortar to SG-OSL stimulation.

As a general conclusion, it is evident that further research is definitely needed in order to establish a concise and independently reliable methodology for mortar dating. The results show, however, that such a methodology can most certainly be developed at least for a majority of the mortar samples. Prescreening and characterization of the mortars should become a standard approach prior to the mortar dating in order to understand the failure risks of the dating process and to evaluate the data obtained.

\section{REFERENCES}

Baxter MS, Walton A. 1970. Radiocarbon dating of mortars. Nature 225(5236):937-8.

Binda L, Baronio G. 1988. Survey of brick/binder adhesion in powdered brick mortars and plasters. Masonry International Journal 2(3):87-92.

Blake EM. 1959. Roman Construction in Italy from Tiberius Through the Flavians. Washington, DC.

Boynton RS. 1980. Chemistry and Technology of Lime and Limestone. 2nd edition. New York: Wiley Interscience. $592 \mathrm{p}$.

Folk RL, Valastro S. Jr. 1976. Successful technique for dating of lime mortars by carbon-14. Journal of Field Archaeology 3:203-8.

Folk RL, Valastro S. Jr. 1979. Dating of lime mortar by ${ }^{14} \mathrm{C}$. In: Berger R, Suess HE, editors. Proceedings of the 9th International Conference on Radiocarbon Dating, 1976. Los Angeles/La Jolla.

Hajdas I, Lindroos A, Heinemeier J, Ringbom A, Marzaioli F, Terrasi F, Passariello I, Capano M, Artioli G, Addis A, Secco M, Michalska D, Czernik J, Goslar T, Hayen R, Van Strydonck M, Fontaine L, Boudin M, Maspero F, Panzeri L, Galli A, Urbanova P, Guibert P. 2017.
Preparation and dating of mortar samplesMortar Dating Inter-comparison Study (MODIS). Radiocarbon 59(6):this issue.

Hayen R, Van Strydonck M, Boaretto E, Lindroos A, Heinemeier J, Ringbom A, Hueglin S, Michalska D, Hajdas I, Marzaoili F, Maspero F, Galli A, Artioli G, Moreau C, Guibert P, Caroselli M. 2016. Analysis and characterisation of historic mortars for absolute dating. In: Proceedings of the 4th Historic Mortars Conference (HMC 2016). 10-12 October 2016. Santorini. In press.

Heinemeier J, Jungner H, Lindroos A, Ringbom Å, von Konow T, Rud N. 1997. AMS ${ }^{14} \mathrm{C}$ dating of lime mortar. Nuclear Instruments and Methods in Physics Research B 123(1-4):487-95.

Hueglin S. 2011. Medieval mortar mixers revisited, Basle and beyond. ZAM Zeitschrift für Archäologie des Middelalters 39:189-212.

Hueglin S. 2017. Time framing Early Medieval stone building north of the Alps - a discussion of recent challenging results. Radiocarbon 59(6): this issue.

Labeyrie J, Delibrias G. 1964. Dating of old mortars by the carbon-14 method. Nature 201(4920):742. 
Lancaster L. 2005. Concrete vaulted construction in imperial Rome. Innovations in Context. 58-9.

Lindroos A, Heinemeier J, Ringbom Å, Braskén M, Sveinbjörnsdóttir Á. 2007. Mortar dating using AMS ${ }^{14} \mathrm{C}$ and sequential dissolution: examples from Medieval, non-hydraulic lime mortars from the Åland Islands, SW Finland. Radiocarbon 49(1):47-67.

Lindroos A, Heinemeier J, Ringbom A, Brock F, SonckKoota P, Pehkonen M, Suksi J. 2010. Problems in radiocarbon dating of Roman pozzolana mortars. Commentationes Humanarum Litterarum 128. Societas Scientiarum Fennica. p 214-30.

Marzaioli F, Nonni S, Passariello I, Capano M, Ricci P, Lubritto C, De Cesare N, Eramo G, Castillo JAQ, Terrasi F. 2013. Accelerator mass spectrometry ${ }^{14} \mathrm{C}$ dating of lime mortars: methodological aspects and field study applications at CIRCE (Italy). Nuclear Instruments and Methods in Physics Research B 294:246-51.

Michalska D, Czernik J. 2015. Carbonates in leaching reactions in context of ${ }^{14} \mathrm{C}$ dating. Nuclear Instruments and Methods in Physics Research B 361:431-9.

Michalska D, Czernik J, Gosar T. 2017. Methodlogical aspect of mortars dating (Poznan, Poland, MODIS). Radiocarbon 59(6):this issue.

Nawrocka D, Michniewicz J, Pawlyta J, Pazdur A. 2005. Application of radiocarbon method for dating of lime mortars. Geochronometria 24:109-15.

Nawrocka D, Czernik J, Goslar T. 2009. ${ }^{14}$ C dating of carbonate mortars from Polish and Israeli sites. Radiocarbon 51(2):857-66.

Ringbom Å, Heinemeier J, Lindroos A, Brock F. 2011. Mortar dating and Roman pozzolana, results and interpretations. Commentationes Humanarum Litterarum 128. Societas Scientiarum Fennica. 187-208.

Ringbom Å, Lindroos A, Heinemeier J, Sonck-Koota P. 2014. 19 years of mortar dating: learning from experience. Radiocarbon 56(2):619-35.

Sjöberg P, Lindroos A, Ringbom Å. 2011. Radiocarbon dating of the medieval churches of the Åboland Archipelago. In: Hansson J, Ranta H, editors. Archaeology and History of Churches in the Baltic Region. p 171-95.

Sonninen E, Jungner H, Erametsa P. 1984. Dating of mortar and bricks from the castle of Kastelholm. In: Edgren T, Junger H, editors. Proceedings of the 3rd Conference on the Application of Scientific Methods in Archaeology. Helsinki: Iskos.

Sonninen E, Jungner H. 2001. An improvement in preparation of mortar for radiocarbon dating. Radiocarbon 43(2A):271-3.

Urbanova P, Hourcade D, Ney C, Guibert P. 2015. Sources of uncertainties in OSL dating of archaeological mortars: the case study of the Roman amphitheatre Palais-Gallien in Bordeaux. Radiation Measurements 72:100-10.

Urbanova P, Guibert P. 2017. Methodological study on single grain OSL dating of mortars: comparison of five reference archaeological sites. Geochronometria. https://doi.org/10.1515/geochr2015-0050.

Van Strydonck M, Dupas M, Dauchot-Dehon M, Pachiaudi C, Marechal J. 1986. The influence of contaminating (fossil) carbonate and the variation of $\delta^{13} \mathrm{C}$ in mortar dating. Radiocarbon $28(2 \mathrm{~A})$ : 702-10. 